\title{
Iot-Based Personal Protective Equipment Monitoring System To Prevent The Risk Of Dehydration In Health Workers For COVID-19 Pandemic
}

\author{
Rafa Raihan Fadilla ${ }^{1 *}$, Andi Nurul Isri Indriany Idhil ${ }^{2}$, Monika Ayu Puji Anggraini ${ }^{3}$, Muhammad Yogi \\ Nurrohman ${ }^{4}$, Raihan Zhifhanur Muhammad ${ }^{5}$, Zainul Abidin, ${ }^{6}$ \\ 1,4,5 Jurusan Teknik Elektro, Fakultas Teknik Universitas Brawijaya \\ 2,3 Pendidikan Dokter, Fakultas Kedokteran Universitas Brawijaya \\ ${ }^{*}$ Corresponding author: \\ Email: rafarfadilla@student.ub.ac.id
}

\begin{abstract}
The extraordinary case of Covid-19 has made health workers the front line in handling it. To prevent the risk of contracting, health workers must use Personal Protective Equipment (PPE) as protection. PPE that must be worn for at least 5 hours a day and is waterproof makes users experience much sweating. If not prevented, health workers can be exposed to dehydration and even death. Based on the explanation above, PPE has been designed that can cool IoT-based health workers. Also, all activities can be monitored remotely via the WEB, accessible via a smartphone or computer. In addition to $W E B$, data can be displayed via the LCD. The DHT22 sensor and the airflow sensor will detect the hazmat's temperature, humidity, and airflow. Furthermore, the tool is also equipped with UVC rays that can clean the air from microorganisms. Activity data will be stored in cloud storage, which is helpful as an evaluation material and reference for health workers' health progress. From the tests' results, the tool will function when the temperature and humidity follow the setpoint.
\end{abstract}

Keywords: Internet of Things, Monitoring, Personal Protective Equipment, Dehydration, Covid-19.

\section{INTRODUCTION}

In December 2019, the world was shocked by the Covid-19 outbreak in Wuhan, China. This outbreak is caused by a coronavirus called Severe Acute Respiratory Syndrome Coronavirus-2 (SARSCoV2) (Susilo, et al., 2020). Common symptoms of people exposed to Covid-19 are fever, cough, shortness of breath, nausea, diarrhea, and digestive system symptoms (Kementerian Kesehatan Republik Indonesia, 2020). However, symptoms of Covid-19 also emerged, such as the appearance of rashes on the skin, muscle aches, coughing up phlegm, red and watery eyes, and fatigue (Muvianto \& Yuniarto, 2020). The transmission line for Covid-19 is droplets from the respiratory tract and the contact produced when someone sneezes and coughs (WHO, 2020a). The incubation period for Covid-19 ranges from 5-6 days, with the longest being 14 days. In the worst cases, Covid-19 can cause a person to experience pneumonia, acute respiratory syndrome, kidney failure, and even death (Kementerian Kesehatan Republik Indonesia, 2020). The World Health Organization (WHO) has declared the Covid-19 outbreak globally as a pandemic case (Susilo, et al., 2020). This case is one of the biggest problems in the world regarding health after the second world war (Morabito, et al., 2020). The Covid-19 outbreak creates the toughest challenge for the entire world community, especially health workers at the forefront. Every day, health workers treat patients with or without Covid-19 symptoms (Foula, et al., 2021).Health workers on duty must use PPE because they have a major risk of transmitting Covid-19, especially to isolation ward officers, intensive care units, and emergency units (WHO, 2020b). PPE is special equipment or clothing consisting of masks, eye protection, face shields, medical gowns, medical gloves, head coverings, and protective shoes to reduce the risk of transmitting Covid-19 (Burton, et al., 2020).

The use of PPE to prevent virus transmission has been demonstrated previously during the Severe Acute Respiratory Syndrome (SARS) outbreak Moore, et al. (2005) and the Ebola epidemic Fischer, et al. (2015). Besides having to work around the clock, health workers must also adapt to the surrounding environment when using PPE (Tumram, 2020). The temperature during summer in tropical countries, e.g., India, can exceed $114.8^{\circ} \mathrm{F}$. Many health facilities are not equipped with Air Conditioner (AC). 
Increased body heat accompanied by physical intensity, hot temperatures, and humidity have a higher risk of exposure to disease (Kulkarni, 2007).In terms of quality, the PPE design currently used is not under the specific characteristics of Covid-19. Besides having a limited stock, the use of PPE tends to make health workers feel uncomfortable, primarily with prolonged use (Vidua, et al., 2020). PPE is designed only to be used for 2-3 hours. Studies show that working with PPE for more than 4 hours can make health workers experience headaches (Ong, et al., 2020). Meanwhile, Covid-19 cases have increased, forcing health workers to extra hours to treat patients. Health workers also reported that the use of PPE causes skin irritation, trichotillomania, and increased temperature, significantly reducing the effectiveness of PPE (Locatelli, et al., 2014). Intensive use of PPE during Covid-19 can also cause sensory problems, such as problems with vision and hearing. It disrupts health workers' performance and even endangers their patients' health and theirs (Shenal, et al., 2012).PPE is designed with impermeable materials that inhibit body heat loss and limited additional space for health workers when using PPE (Coca, et al., 2017). It can cause an increase in heat stress and heat strain on health workers. The effects of heat stress, such as complaining of the heat, sweating, always thirsty, uncomfortable, and loss of appetite, are caused by loss of fluid from the body by evaporation in the form of sweat (Davey, et al., 2021). Some of these symptoms tend to indicate heat exhaustion and dehydration. If severe, it can cause a person to have a heat stroke and even a health worker to fall while on duty (Tumram, 2020).

When working, particularly in high ambient temperatures, the standard methods to reduce body temperature are drinking lots of water, dividing work and rest, wearing cotton clothes, or working slowly. However, health workers wearing PPE cannot apply such adjustments on duty. Hence, it can disrupt the performance of health workers and cause unwanted conditions, such as dehydration. Therefore, it is highly recommended that health workers use PPE made from moisture-absorbing fabrics made of polyester, polypropylene, nylon, bamboo, and micro modal (Tumram, 2020). Dehydration is fluid loss from several parts of the body characterized by sweating, feeling weak, and even fainting. Dehydration can be caused by an increase in fluid requirements from intake so that the volume of fluid in the blood decreases (Benton, 2011). Dehydration also affects the ability of performance. If not treated immediately, it can cause health problems, disability, and even death (Aprillia \& Khomsan, 2014).Loss of fluid in the form of sweat results from evaporation, which depends on environmental temperature, humidity, and wind speed. The higher the temperature and the lower the humidity, the fluid loss will increase. Meanwhile, normal human body temperature has a range of $36.5^{\circ} \mathrm{C}-37.5^{\circ} \mathrm{C}$ and ideal humidity of $40 \%$ RH-60\% RH (Gibson, et al., 2012). The development and study of PPE equipped with air conditioners in it are limited. Sterman, et al. (2021) stated that an Air Shade project had been developed in Israel to use health workers dealing with Covid-19. The Air Shade project is designed on PPE while still paying attention to the ergonomic side to provide comfort for health workers.

The leading concept of the system is to circulate filtered air over the face of the health worker using a headband. The designed headband has a vent nozzle connected to a High-Efficiency Particulate Air (HEPA) filter and a compressor unit that hangs by a belt above the health worker's pelvis. Some parts of the Air Shade System are disposable, and the rest must be cleaned before reuse.Moreover, another PPE development was carried out by Dr. Darmawan Ismail and the team from Semarang State University (UNS). The PPE used water-repellent material. It claimed not to make the health workers hot when wearing it and is safe due to its respiratory tract. The PPE was called Surgeons of UNS (SUNS) Protective Equipment (Proque). SUNS Proque is equipped with tools to filter viruses. The filter uses a sponge and detergent water. They selected a sponge since the fibers are dense and irregular. Hence, it maximizes filtration, helps air humidity, regulates temperature, and gives fragrance. PPE was designed up and down with an internal mini fan to help suck outside air through the air filter to make the body lighter during inspiration and lasts longer (UNS, 2020). The authors also developed PPE for air cooler during use and remote monitoring based on ESP32. The PPE has a portable tube to facilitate health workers to carry and is easily attached to a modified hazmat suit. Also, the tube is equipped with UVC rays to clean the air from microorganisms. UV light is used, acting as a germicidal agent. Exposure to UV type C light with a wavelength below $260 \mathrm{~nm}$ can kill biological agents, such as bacteria and viruses (Gutiérrez, et al., 2015). 
The sensor utilized was the DHT22 sensor to read temperature and humidity, and the airflow sensor detects airflow in the PPE of health workers. The two sensors will work integrated to make the tool system efficient.

\section{METHOD}

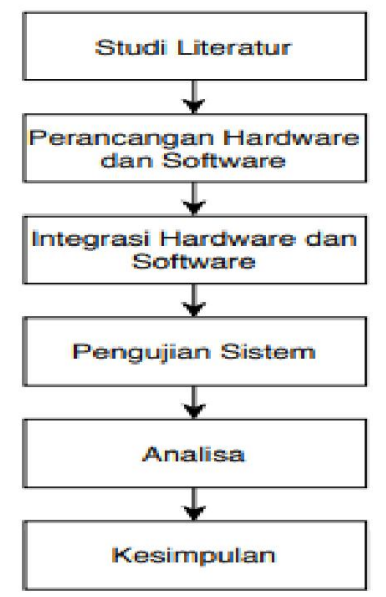

Fig 1. Study Framework

Figure 1 shows that the study process method began with a literature study. At this stage, the authors studied and read literature related to the study. Libraries used as references were scientific journals, books, or sources from the internet. Then, the authors made the design of hardware, software, and electronic circuit schematic.

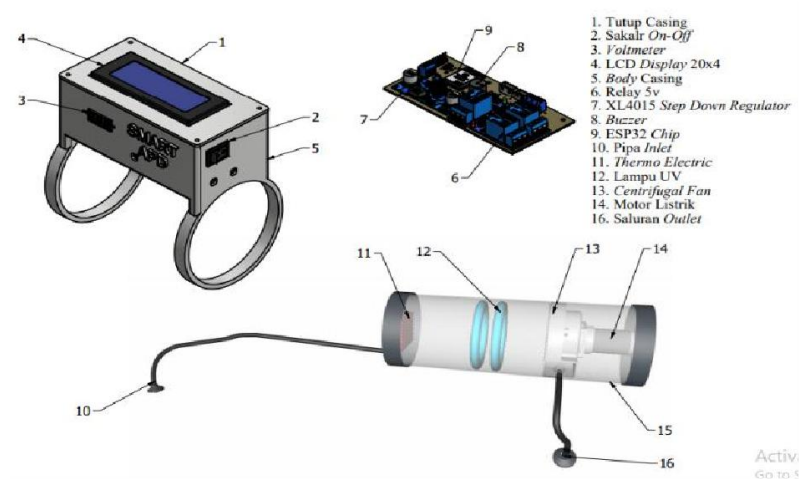

(a)

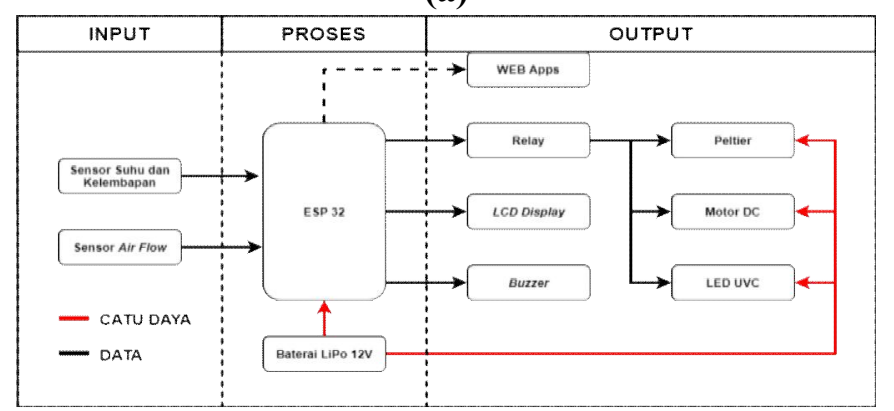

(b)

Fig 2. (a) Design Illustration (b) Hardware Diagram Block

The author constructed the appropriate design at the hardware design stage, as presented in the picture. The material used in the tube and box was Acrylonitrile Butadiene Styrene (ABS) plastic. The size of the tube was $7.62 \mathrm{~cm}$ in diameter and $36 \mathrm{~cm}$ in height. Moreover, the box volume was $13.5 \mathrm{x} 5.5 \mathrm{x} 7 \mathrm{~cm}^{3}$. Meanwhile, the material used to modify the hazmat suit was polyester. Tubes and boxes contain electronic components that function to run the entire system on the equipment to be used.This tool employed a $12 \mathrm{~V}$ LiPo battery as the main power supply. The input to the device consists of a DHT22 
sensor and an airflow sensor. The device's output is a relay module that controls the centrifugal fan, Peltier, and UVC LED. This tool is also equipped with an LCD and a buzzer to indicate unsuitable air temperature. An ESP32 microcontroller was used as a data processor since the Internet of Things (IoT) feature is required in this tool. The temperature reading data will be sent to the monitoring web to monitor the health condition of the health workers.

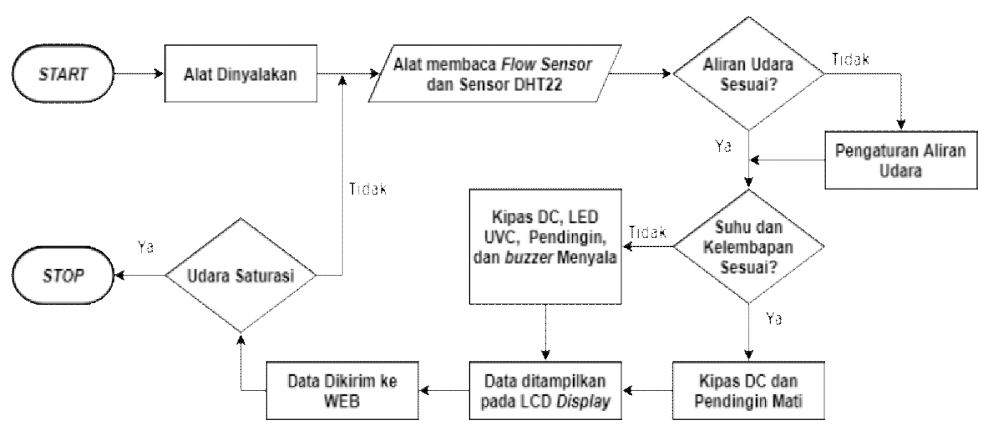

Fig 3. Flow Diagram

Furthermore, at the software design stage, the authors built a software design that is the system flow of the entire study.

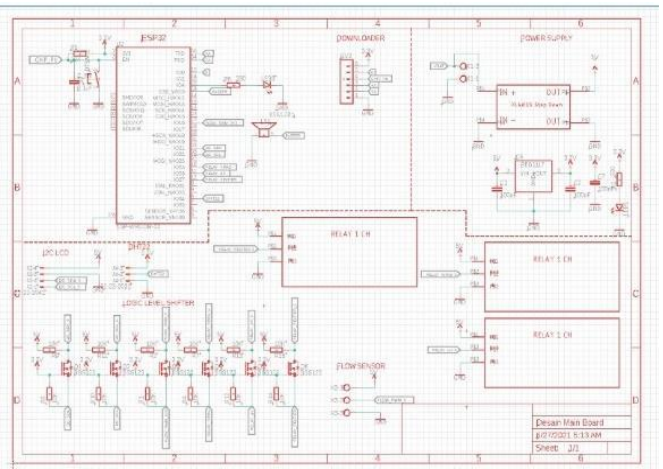

Fig 4. Overall Electrical Sequence

Figure 4 presents the overall electronic circuit used in this tool system. The electronics circuit consists of an LCD, ESP32, DHT22 sensor, airflow sensor, buzzer, centrifugal fan, voltmeter, Peltier, UVC LED, stepdown module, $12 \mathrm{~V}$ LiPo battery, and relay.

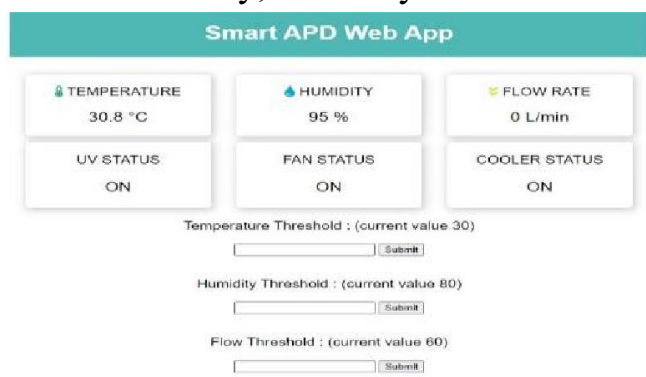

Fig 5. Monitoring Web Display

The tool application is accessible via a PC or mobile browser (Personal Computer). Account creation will be adjusted with channel creation to monitoring the tools. The monitoring web display is shown in Figure 5. At the hardware and software integration stage, the authors connected the two devices to become a system to work as a whole and continuously. Then, the authors tested the tools separately and thoroughly in one system. At the stage of analysis and conclusion, the authors summarized the study to acquire the desired results. 


\section{RESULT AND DISCUSSION}

Several tests and analyses were carried out on the entire tool in the results and discussion, both on input and output. Sensor testing and analysis were performed to determine whether the sensor is appropriately functioning as planned. The tests carried out are as follows:

\section{Battery Resistance Test Result}

This test was performed by measuring current and voltage consumption periodically to determine the resistance of the tool during use.
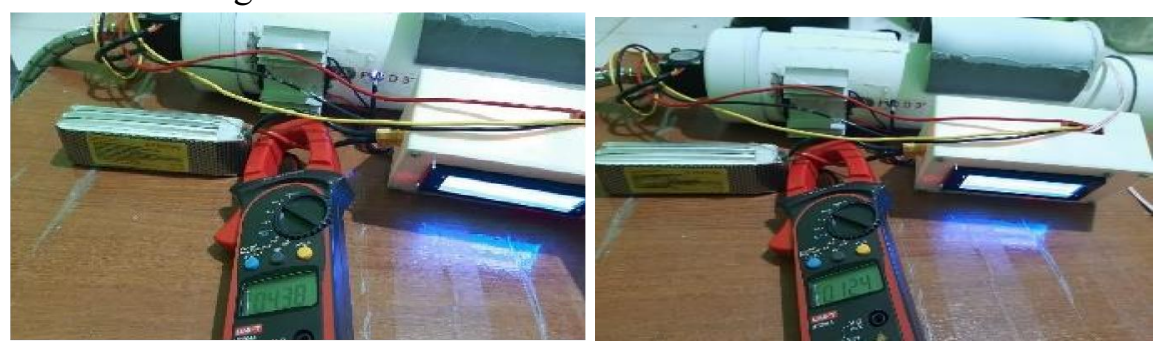

Fig 6. Battery Resistance Test

From the test results, the current consumption was $4.38 \mathrm{~A}$. When the device is on standby, the current was relatively constant by $1.24 \mathrm{~A}$. Meanwhile, the voltage continued to drop from $12.6 \mathrm{~V}$ to $10.9 \mathrm{~V}$ because when the battery's voltage is below $10.9 \mathrm{~V}$, the tool is not functioning correctly. Besides, the battery voltage was relatively constant due to the absence of current consumption. The results of the tests are presented in Figure 7.

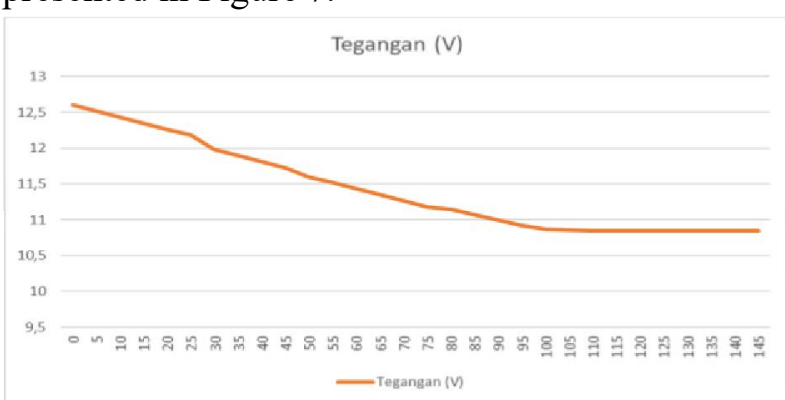

(a)

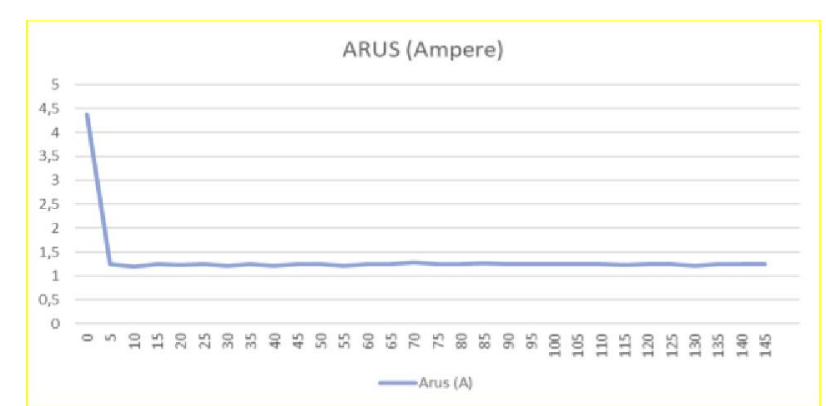

(b)

Fig 7. Battery Resistance Test Graph Result (a) Resistance (b) Current

\section{Cooling System Test Result}

Testing of the cooling system was carried out using the DHT22 sensor. The DHT22 sensor will detect temperature and humidity during PPE use. ESP32 will get from the sensor to be processed and activate the centrifugal fan and Peltier based on a predetermined set point. The setpoint can be determined by setting the threshold. The results of the cooling system test are presented in Table 1 .

Table 1. Cooling System Test Result

\begin{tabular}{ccccc}
\hline $\begin{array}{c}\text { Test } \\
\text { No. }\end{array}$ & $\begin{array}{c}\text { Temperature } \\
\left({ }^{\circ} \mathrm{C}\right)\end{array}$ & $\begin{array}{c}\text { Humidity } \\
(\% \mathrm{RH})\end{array}$ & Fan & Peltier \\
\hline 1 & $<$ th & $<$ th & Off & Off \\
\hline 2 & $<$ th & $>$ th & Off & On \\
\hline 3 & $>$ th & $<$ th & On & Off \\
\hline 4 & $>$ th & $>$ th & On & On \\
\hline 5 & $<$ th & $<$ th & Off & Off \\
\hline 6 & $<$ th & $>$ th & Off & On \\
\hline 7 & $>$ th & $<$ th & On & Off \\
\hline 8 & $>$ th & $>$ th & On & On \\
\hline 9 & $<$ th & $<$ th & Off & Off \\
\hline 10 & $>$ th & $>$ th & On & On \\
\hline
\end{tabular}

NB: th $=$ Threshold 


\section{Air Circulation Test Result}

Air circulation is the main component in PPE, where the centrifugal fan will absorb the hot and humid air inside and passed to the UVC LED to clean from microorganisms and the Peltier to lower the temperature. Figure 8 illustrates the results of the air circulation test.

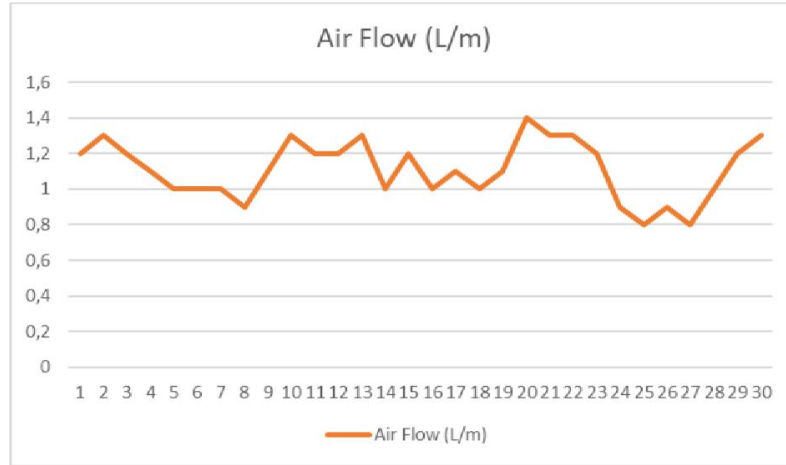

Fig 8. Air Circulation Test Graph Result

From the test results, the airflow value varied due to the temperature and humidity conditions in the PPE.

\section{Data Transmission Test Result}

Data transmission test was performed by first connecting the hotspot from the ESP32 with a PC or cellphone to monitor the condition of health workers. After successfully connecting the device with a PC or cellphone, the data is ready to be displayed on monitoring web. The documentation of the data transmission test results is presented in Figure 9.

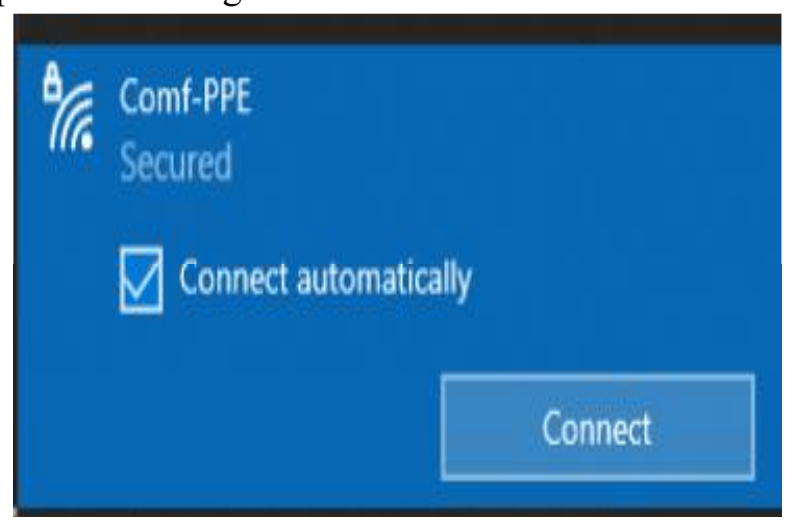

Fig 9. Data Transmission Test

\section{Data Display Test Result}

Data from the device will be displayed on the LCD and sent to the monitoring web. The data to be displayed are temperature, humidity, and airflow. Meanwhile, in addition to these three parameters, the monitoring web can also set the threshold of each parameter. The display of the LCD and monitoring web can be seen in Figure 10.

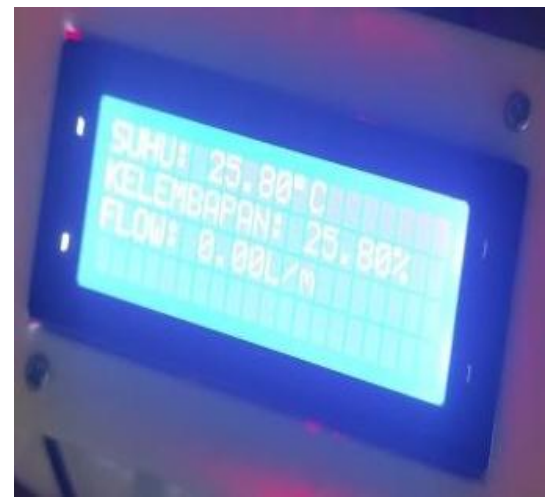

(a)

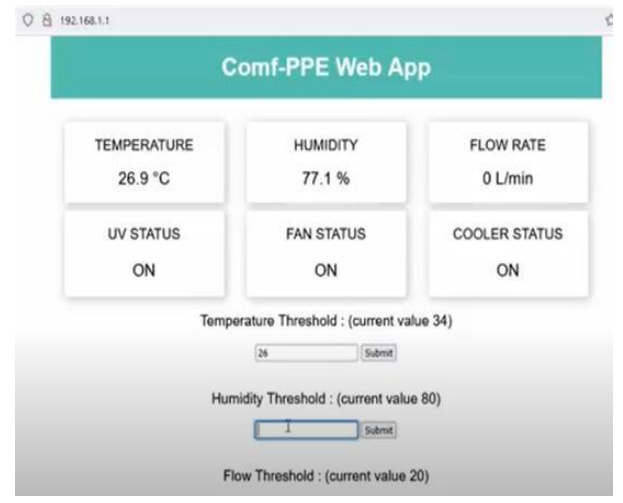

(b)

Fig 10. Data Display (a) LCD (b) Monitoring Web 


\section{Overall System Test Result}

Testing was carried out by trying the tool to determine the performance of the system as a whole. The tool has been able to function correctly as a whole as expected.

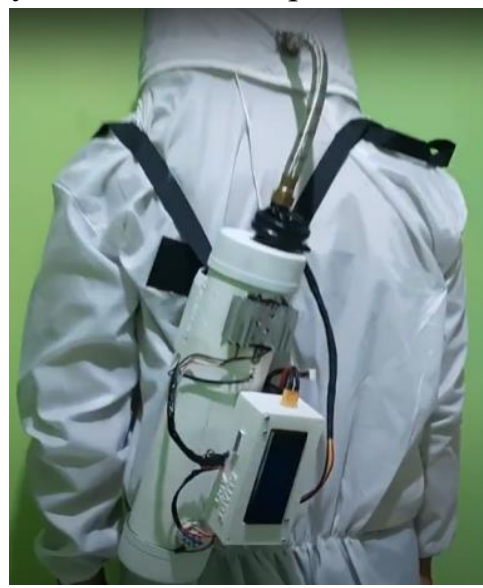

Fig 11. Overall System Test

IV. CONCLUSION

Based on the results and discussions in this study, several conclusions can be obtained as follows:

1. From the battery resistance test results, it can be concluded that when the voltage is below 10.9 $\mathrm{V}$, the device is not functioning properly.

2. From the test results of the cooling system, it can be concluded that the centrifugal fan and Peltier will run based on the set point that has been determined by setting the threshold.

3. From the air circulation test results, it can be concluded that the airflow value varies due to the temperature and humidity conditions in the PPE.

4. From the test results of data transmission, it can be concluded that the system will be active if it is first connected to a hotspot from ESP32.

5. From the results of testing the appearance of the data, it can be concluded that the temperature, humidity, and airflow data will be displayed on the LCD and monitoring web. In the monitoring web, one can also set the threshold of each parameter.

6. From the results of testing the whole system, it can be concluded that the tool is appropriately functioning as expected.

\section{ACKNOWLEDGMENTS}

The authors are grateful to Republic of Indonesia Ministry of Education, Culture, Research, and Technology and Brawijaya University for supporting this research program.

\section{REFERENCES}

[1] Aprillia, D. D., \& Khomsan, A. 2014. Konsumsi Air Putih, Status Gizi, dan Status Kesehatan Penghuni Panti Werda di Kabupaten Pacitan. Jurnal Gizi dan Pangan. 9 (3): 167-172.

[2] Benton, D. 2011. Dehydration Influences Mood and Cognition: a Plausible Hypothesis? Journal Nutrients. 3 (5): 559-565.

[3] Burton, C., Adisesh, A., Burton, C., \& Chan, X. H. 2020. The Efficacy of PPE for Covid-19-Type Respiratory Illnesses in Primary and Community Care Staff. British Journal of General Practice. 70 (4): $1-4$.

[4] Coca, A., Quinn, T., Kim, J. H., Wu, T., Powell, J., Roberge, R., \& Shaffer, R. 2017. Physiological Evaluation of Personal Protective Ensembles Recommended for Use in West Africa. Disaster Medicine and Public Health Preparedness. 11 (5): 1-7.

[5] Davey, S. L., Lee, B. J., Robbins, T., Randeva, H., \& Thake, C. D. 2021. Heat Stress and PPE during Covid-19: Impact on Healthcare Workers' Performance, Safety and Well Being in NHS Settings. Journal of Hospital Infection. 108 (1): 185-188.

[6] Fischer, W. A., Hyness, N. A., \& Perl, T. M. 2015. Protecting Health Care Workers from Ebola: Personal Protective Equipment is Critical but is not Enough. Annals of Internal Medicine. 161 (10): 753-754. 
[7] Foula, M. S., Nwesar, F. A., Oraby, E. H., Foula, A., Alarfaj, M. A., Foula, H. S., \& Mohamed, N. E. 2021. Does Wearing Personal Protective Equipment Affect the Performance and Decision of Physicians? A Cross Sectional Study During the Covid-19 Pandemic. Annals of Medicine and Surgery. 67 (1): 1-5.

[8] Gibson, S., Gunn, P., \& Maughan, R. J. 2012. Hydration, Water Intake, and Beverage Consumption Habits among Adults. Nutrition Bulletin. 37 (3): 182-192.

[9] Gutiérrez, D. R., Char, C., Escalona, V. H., Chaves, A. R., \& Rodriguez, S. D. 2015. Application of UVC Radiation in the Conservation of Minimally Processed Rocket (Eruca Sativa Mill.). Journal of Food Processing and Preservation. 39 (6): 3117-3127.

[10] Kementerian Kesehatan Republik Indonesia. 2020. Pedoman Pencegahan dan Pengendalian Coronavirus Disease (Covid-19). URL: https://www.kemkes.go.id/article/view/20031700001/Dokumen-Resmi-danProtokol-Penanganan-COVID-19.html. Diakses tanggal 28 Juni 2021.

[11] Kulkarni, G. K. 2007. Construction Industry: More Needs to be Done. Indian Journal of Occupational and Enviromental Medicine. 11 (1): 1-2.

[12] Locatelli, S. M., Lavela, S. L., \& Gosch, M. 2014. Health Care Workers' Reported Discomfort while Wearing Filtering Face Piece Respirators. Workplace Health and Safety. 62 (9): 362-368.

[13] Moore, D., Gamage, B., Bryce, E., Copes, R., \& Yassi, A. 2005. Protecting Health Care Workers from SARS and Other Respiratory Pathogens: Organizational and Individual Factors that Affect Adherence to Infection Control Guidelines. American Journal of Infection Control. 33 (2): 88-96.

[14] Morabito, M., Messeri, A., Crisci, A., Pratali, L., Bonafede, M., \& Marinaccio, A. 2020. Heat Warning and Public and Workers' Health at the Time of Covid-19 Pandemic. Science of the Total Environment. 738 (1): 1-6.

[15] Muvianto, C. M., \& Yuniarto, K. 2020. Pemanfaatan UVC Chamber sebagai Disinfektan Alat Pelindung Diri untuk Pencegahan Penyebaran Virus Corona. Jurnal Abdi Insani Universitas Mataram. 7 (1): 87-92.

[16] Ong, J. J., Bharatendu, C., Goh, Y., Tang, J. Z., Sooi, K. W., Tan, Y. L., . . . Sharma, V. K. 2020. Headaches Associated with Personal Protective Equipment - A Cross Sectional Study Among Frontline Healthcare Workers. Headache: The Journal of Head and Face Pain. 60 (5): 864-877.

[17] Shenal, B. V., Radonovich, L. J., Cheng, J., Hodgson, M., \& Bender, B. S. 2012. Discomfort and Exertion Associated with Prolonged Wear of Respiratory Protection in a Health Care Setting. Journal of Occupational and Environmental Hygiene. 9 (1): 59-64.

[18] Sterman, Y., Tarazi, E., Berman, O., Gur, Y., Parnas, H., Tareef, R., \& Arwas, S. 2021. Safety on Demand: A Case Study for the Design and Manufacturing on Demand of Personal Protective Equipment for Healthcare Workers during the Covid-19 Pandemic. Safety Science. 136 (1): 1-6.

[19] Susilo, A., Rumende, C. M., Pitoyo, C. W., Santoso, W. D., Yulianti, M., Herikurniawan, .. . Yunihastuti, E. 2020. Coronavirus Disease 2019: Tinjauan Literatur Terkini. Jurnal Penyakit Dalam Indonesia. 7 (1): 45-67.

[20] Tumram, N. K. 2020. Personal Protective Equipment and Personal Cooling Garments to Reduce Heat Related Stress and Injuries. Medico Legal Journal. 88 (1): 1-4.

[21] UNS. 2020. Dosen FK UNS Berinovasi Menciptakan APD. URL: https://uns.ac.id/id/uns-update/dosen-fkuns-berinovasi-menciptakan-apd.html. Diakses tanggal 24 Juni 2021.

[22] Vidua, R. K., Chouksey, V. K., Bhargava, D. C., \& Kumar, J. 2020. Problems Arising from PPE when Worn for Long Periods. Medico Legal Journal. 88 (15): 47-49.

[23] WHO. 2020a. Water, Sanitation, Hygiene and Waste for the Covid-19 Virus. URL: https://apps.who.int/iris/rest/bitstreams/1292822/retrieve. Diakses tanggal 24 Juni 2021.

[24] WHO. 2020b. Rational Use of Personal Protective Equipment for Covid-19 and Considerations during Severe Shortages. URL: https://apps.who.int/iris/bitstream/handle/10665/338033/WHO-2019-nCoVIPC_PPE_use-2020.4-eng.pdf. Diakses tanggal 25 Juni 2021. 